\title{
Co-expression of the Arabidopsis SOS genes enhances salt tolerance in transgenic tall fescue (Festuca arundinacea Schreb.)
}

\author{
Dong-Mei Ma • Wei-Rong Xu • Hui-Wen Li • \\ Feng-Xia Jin $\cdot$ Ling-Na Guo $\cdot$ Jing Wang • \\ Hong-Jun Dai • Xing Xu
}

Received: 27 May 2013 / Accepted: 12 August 2013 /Published online: 11 September 2013

(C) The Author(s) 2013. This article is published with open access at Springerlink.com

\begin{abstract}
Crop productivity is greatly affected by soil salinity; therefore, improvement in salinity tolerance of crops is a major goal in salt-tolerant breeding. The Salt Overly Sensitive $(S O S)$ signal-transduction pathway plays a key role in ion homeostasis and salt tolerance in plants. Here, we report that overexpression of Arabidopsis thaliana SOS1+SOS2+SOS3 genes enhanced salt tolerance in tall fescue. The transgenic plants displayed superior growth and accumulated less $\mathrm{Na}^{+}$ and more $\mathrm{K}^{+}$in roots after $350 \mathrm{mM} \mathrm{NaCl}$ treatment. Moreover, $\mathrm{Na}^{+}$enflux, $\mathrm{K}^{+}$influx, and $\mathrm{Ca}^{2+}$ influx were higher in the transgenic plants than in the wild-type plants. The activities of the enzyme superoxide dismutase, peroxidase, catalase, and proline content in the transgenic plants were significantly increased; however, the malondialdehyde content decreased in transgenic plants compared to the controls. These results suggested that co-expression of $A$. thaliana $S O S 1+S O S 2+S O S 3$ genes enhanced the salt tolerance in transgenic tall fescue.
\end{abstract}

Keywords $S O S$ pathway genes $\cdot$ Salt stress $\cdot$ Transgenic tall fescue

Handling Editor: Peter Nick

Electronic supplementary material The online version of this article (doi:10.1007/s00709-013-0540-9) contains supplementary material, which is available to authorized users.

D.-M. Ma • W.-R. Xu $\cdot$ H.-W. Li • F.-X. Jin · J. Wang • H.-J. Dai •

X. Xu $(\bowtie)$

School of Agronomy, Ningxia University, Yinchuan 750021, China

e-mail: ma_dm@nxu.edu.cn

L.-N. Guo

School of Life Science, Ningxia University, Yinchuan 750021, China

\section{Introduction}

Abiotic stresses, such as salinity, drought, and freezing, greatly limit plant growth, development, and productivity (Yamaguchi-Shinozaki et al. 2002; Huai et al. 2009; Jin et al. 2010). Soil salinity is one of these environmental abiotic stresses that decrease plant growth and productivity. It has been well documented that excessive soluble ions including sodium and chloride are harmful to most plants, including all major crops (Zhu 2001). The damage of salinity to crops is mainly caused by sodium ion accumulation, a high concentration of which causes water deficit and enzyme inactivity in most plant organs and cells (Zhu 2000). Sodium accumulation in cell walls can rapidly lead to osmotic stress and cell death (Munns 2002). $\mathrm{Na}^{+}$is not essential for plant growth, and under salt stress, it hinders uptake of the important mineral nutrient $\mathrm{K}^{+}$and competes for its enzyme binding sites. Maintaining a high $\mathrm{K}^{+}$and low $\mathrm{Na}^{+}$homeostasis in the cytoplasm is thus essential for plant salt tolerance. Plants prevent excessive $\mathrm{Na}^{+}$ accumulation in the symplast by restricting influx, increasing efflux, and increasing vacuolar sequestration of $\mathrm{Na}^{+}$(Tester and Davenport 2003).

The SOS pathway is currently one of the most extensive studied mechanisms in controlling salt stress response in plants. The SOS pathway is responsible for ion homeostasis and salt tolerance in plants (Zhu 2003). The SOS1, SOS2, and SOS3 loci were first identified through forward genetic screens for salt-hypersensitive growth (Zhu 2002). AtSOS1 is a plasma membrane $\mathrm{Na}^{+} / \mathrm{H}^{+}$antiporter and mediates $\mathrm{Na}^{+}$ efflux and control long-distance $\mathrm{Na}^{+}$transport from roots to shoots while protecting individual cells from $\mathrm{Na}^{+}$toxicity (Shi et al. 2000). AtSOS2 is a serine/threonine protein kinase (Liu et al. 2000). AtSOS3 responds to the $\mathrm{Ca}^{2+}$ signal by activating a protein phosphatase or inhibiting a protein kinase (or by 
doing both) that regulates $\mathrm{K}^{+}$and $\mathrm{Na}^{+}$transport systems (Liu and Zhu 1998). AtSOS3 physically interacts with and activates AtSOS2 protein kinase (Halfter et al. 2000). The AtSOS2/AtSOS3 kinase complex phosphorylates and activates the AtSOS1 protein (Quintero et al. 2002). As an essential second messenger, calcium regulates diverse cellular processes in plants. Calcineurin B-like (CBL) proteins belong to $\mathrm{Ca}^{2+}$ sensor protein families and function as sensor relays (Chen et al. 2012).Quan et al. (2007) reported that an AtSOS3 homolog $C B L 10$ appears to be the main mediator for salt tolerance and CBL10 can regulate SOS pathway in Arabidopsis. Under salt stress, the calcium sensor $S O S 3$ activates the kinase SOS2 that positively regulates SOS1. The SOS3 homolog SOS3-like calcium binding protein 8 (SCABP8)/calcineurin B-like 10 (CBL10) functions mainly in the shoot response to salt toxicity. $C B L 10$ is a calcium-binding protein, and calcium enhances SOS2 kinase activity. CBL10 is hypersensitive to salt in shoot tissues and together with $S O S 3$ functions to modulate the activity of SOS2 (Du et al. 2011). CBL10 and SOS3 are only partially redundant in their function, and each plays additional and unique roles in the plant salt stress response (Quan et al. 2007). CBL10 and SOS3 together protect shoots and roots from salt stress, while $C B L 10$ alone partially associates to plasma membranes and recruits SOS2 (Du et al. 2011).

These transgenic reports clearly demonstrated the possibility and feasibility of breeding salt-tolerant plants using the AtSOS pathway genes and CBL10 gene.

Tall fescue (Festuca arundinacea Schreb.) is an important perennial cool-season grass grown or planted in temperate regions worldwide and is widely used for hay and pasture. Adaptation to a wide range of soil conditions, tolerance to continuous grazing, high yield persistence, and compatibility with varied management practices make it a widely used forage grass (Sleper and West 1996; Ge and Wang 2006). However, the growth of tall fescue is severely affected by the salinity soil in some traditional irrigation districts. In the past decade, it has been reported that gene transfer technique was applied to enhance salt tolerance in Tall fescue. Cao et al. (2009) reported the overexpression of transcription factor AtHDG11 in tall fescue resulted in enhanced tolerance to salt stress. Overexpression of both $\mathrm{CuZn}$ superoxide dismutase and ascorbate peroxidase in transgenic tall fescue plants confers increased tolerance to a wide range of abiotic stresses (Lee et al. 2007). Overexpression vacuolar $\mathrm{Na}^{+} / \mathrm{H}^{+}$antiporter gene AtNHXI confers enhanced salt tolerance to the transformed tall fescue progenies (Tian et al. 2006; Zhao et al. 2007). These previous results suggested that overexpression of one salt-tolerant gene could enhance salt tolerance to some degree in tall fescue.

Salt tolerance, like other important agronomic traits in crop plants, is complexly quantitative trait controlled by multi-genes. So far, little information is available on multi-gene cotransformation in tall fescue. Quintero et al. (2002) reported that the SOS system is reconstituted and co-expression of SOS1,
SOS2, and SOS3 confers more salt tolerance than expression of one or two SOS proteins in yeast cells. However, overexpression of $\mathrm{SOS} 1+\mathrm{SOS} 2+\mathrm{SOS} 3$ improved only marginally salt tolerance in Arabidopsis compared to SOS1 - or SOS3 overexpressing Arabidopsis has been documented (Yang et al. 2009). To our knowledge, there are no reports on the improvement of salt tolerance in the tall fescue using co-expression strategy of SOS pathway genes.

In the current study, we attempt to use the genes encoding $S O S 1, S O S 2, S O S 3$, and CBL10 under the control of inducible promoter $r d 29 \mathrm{~A}$ which were transferred into the tall fescue by Agrobacterium-mediated transformation with the aim to modify the salt tolerance in tall fescue. We demonstrated that the co-expression of the Arabidopsis SOS genes (SOS1/SOS2/SOS3) can extrude $\mathrm{Na}^{+}$and involve in $\mathrm{K}^{+}$acquisition in root of tall fescue under $\mathrm{NaCl}$ stress. Moreover, there is a link between $\mathrm{Ca}^{2+}$ transport and SOS pathway (SOS1-SOS2-SOS3). Our data provide a new insight into salt tolerance using the co-expression system of Arabidopsis thaliana SOS1+SOS2+SOS3 genes in transgenic tall fescue.

\section{Materials and methods}

Plant material and embryogenic cells of tall fescue

Mature seeds of tall fescue Arid 3 were obtained from Ningxia University Grass Research Institute, Yinchuan, Ningxia, P.R. China. The seeds were surface sterilized in $70 \%$ ethanol for $2 \mathrm{~min}$ and in $0.1 \% \mathrm{HgCl}_{2}$ for $8 \mathrm{~min}$ and then rinsed with sterilized water for six times. After surface sterilization, seeds were cultured on MS solid medium (Murashige and Skoog 1962) supplemented with $5 \mathrm{mg} / 1$ 2,4-D, $0.1 \mathrm{mg} / 1$ 6-BA, $30 \mathrm{~g} / 1$ sucrose, $2 \mathrm{~g} / \mathrm{l}$ gelrite, and $\mathrm{pH} 5.8$ for embryonic calli induction and then kept in the dark for 3 weeks at $25^{\circ} \mathrm{C}$. During the period, the buds were removed once a week to accelerate calli induction. Calli with shiny, yellowish, and compact structure were selected and subcultured on solid MS medium with $2 \mathrm{mg} / 1$ 2,4-D, $30 \mathrm{~g} / 1$ sucrose, $2 \mathrm{~g} / \mathrm{l}$ gelrite, and $\mathrm{pH} 5.8$ for 2 weeks. The embryonic calli were used for transformation described as previously (Zhao et al. 2005).

\section{Plasmid construction}

The $p S O S$ binary vector is previously generated using multiple-round in vivo site-specific assembly (Chen et al. 2010) (Fig. 1). The target genes of SOS1 (AF256224, 6,076 bp), SOS2 (AF237670, 5,144 bp), SOS3 (AF060553, 2,298 bp), and CBL10 (HE802862, 2,493 bp) involved in the SOS pathway (Quan et al., 2007; Yang et al., 2009) are under the control of the stress-inducible promoter $r d 29 \mathrm{~A}$, respectively. TM1, TM2, and TM220 are the tobacco (Nicotiana tabacum) matrix attachment region (MAR) sequences, which can 


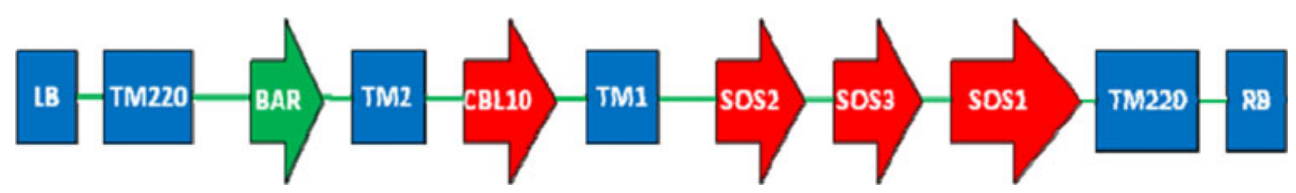

Fig. 1 A schematic diagram of the T-DNA region of expression vector pSOS. $L B$ left border, $R B$ right border, TM220, Bar phosphinothricin acetyltransferase, TM2, CBL10, TM1, SOS2, SOS3, SOS1, TM220,

overcome transgenic silencing and enhance the expression levels of the transgenes (Allen et al. 2000; Xue et al. 2005). The vector includes a Bar resistant gene and was introduced into Agrobacterium tumefaciens strain GV3101 (Berres et al. 1992) via electrophoresis.

Agrobacterium-mediated transformation and transgenic plant regeneration

The infection and co-cultivation of embryonic calli were carried out according to the protocol described (Zhao et al. 2005). The embryonic calli were immersed into $A$. tumefaciens cell suspensions for $15 \mathrm{~min}$ with gentle shaking. The infected calli were then transferred into a Petri dish containing a sheet of sterile filter paper permeated sterile water and co-cultured at $25^{\circ} \mathrm{C}$ in the dark for 3 days. After co-cultivation, the infected calli were rinsed three times with sterile water containing $300 \mathrm{mg} / \mathrm{l}$ cefotaxime and make calli dry with sterile filter paper. Afterward, the infected calli were placed on selection medium (MS solid medium plus $3 \mathrm{mg} / \mathrm{l}$ 2,4-dichlorophenoxyacetic acid, $500 \mathrm{mg} / \mathrm{l}$ Casein acid hydrolysate, $5 \mathrm{mg} / \mathrm{l}$ glufosinate, $300 \mathrm{mg} / \mathrm{l}$ cefotaxime) and cultured in the dark at $25^{\circ} \mathrm{C}$ for 4 weeks. Glufosinate-resistant calli were selected and transferred onto the same selection media. After 30 days, glufosinate-resistant calli were transferred onto the regeneration medium (MS solid medium plus $2 \mathrm{mg} / \mathrm{l} 6-$ benzylaminopurine, $1 \mathrm{mg} / \mathrm{l}$ kinetin, $3 \mathrm{mg} / \mathrm{l}$ glufosinate, $300 \mathrm{mg} /$ 1 cefotaxime) until the buds grew at about $5-6 \mathrm{~cm}$. The medium for forming the multiple shoots was half-strength MS medium containing $3 \mathrm{mg} / \mathrm{l}$ glufosinate. The rooted plants were shifted to soil and grown under greenhouse conditions.

\section{Identification of transgenic plants}

Genomic DNA of untransformed plants regenerated from calli (WT) and transgenic plants were extracted using CTAB method as previously described (Murray and Thompson 1980). The fragment of Bar, SOS1, SOS2, SOS3, and CBL10 genes is $463,700,550,683$, and 460 bp respectively, which were detected by PCR with the following primer pairs (Electronic supplementary material, Table 1).

Bar: $94.0^{\circ} \mathrm{C}, 5 \mathrm{~min} ; 94.0^{\circ} \mathrm{C}, 30 \mathrm{~s} ; 58.0^{\circ} \mathrm{C}, 30 \mathrm{~s} ; 72.0^{\circ} \mathrm{C}$, $1 \mathrm{~min} ; 72.0^{\circ} \mathrm{C}, 5 \mathrm{~min} ; 4.0^{\circ} \mathrm{C}$

SOS1 : $94.0^{\circ} \mathrm{C}, 5 \mathrm{~min} ; 94.0^{\circ} \mathrm{C}, 30 \mathrm{~s} ; 53.0^{\circ} \mathrm{C}, 30 \mathrm{~s} ; 72.0^{\circ} \mathrm{C}$, $1 \mathrm{~min} ; 72.0^{\circ} \mathrm{C}, 5 \mathrm{~min} ; 4.0^{\circ} \mathrm{C}$
TM1, TM2, and TM220 are the MAR sequences, can overcome transgenic silencing, and enhance the expression levels of the transgenes

SOS 2 : $94.0^{\circ} \mathrm{C}, 5 \mathrm{~min} ; 94.0^{\circ} \mathrm{C}, 30 \mathrm{~s} ; 52.0^{\circ} \mathrm{C}, 30 \mathrm{~s} ; 72.0^{\circ} \mathrm{C}$, $1 \mathrm{~min} ; 72.0{ }^{\circ} \mathrm{C}, 5 \mathrm{~min} ; 4.0^{\circ} \mathrm{C}$

SOS3 : $94.0^{\circ} \mathrm{C}, 5 \mathrm{~min} ; 94.0^{\circ} \mathrm{C}, 30 \mathrm{~s} ; 59.0^{\circ} \mathrm{C}, 30 \mathrm{~s} ; 72.0^{\circ} \mathrm{C}$, $1 \mathrm{~min} ; 72.0^{\circ} \mathrm{C}, 5 \mathrm{~min} ; 4.0^{\circ} \mathrm{C}$

CBL10: $94.0^{\circ} \mathrm{C}, 5 \mathrm{~min} ; 94.0^{\circ} \mathrm{C}, 30 \mathrm{~s} ; 57.0^{\circ} \mathrm{C}, 30 \mathrm{~s} ; 72.0^{\circ} \mathrm{C}$, $1 \mathrm{~min} ; 72.0^{\circ} \mathrm{C}, 5 \mathrm{~min} ; 4.0^{\circ} \mathrm{C}$

PCR products were separated on a $1 \%$ agarose gel.

Southern blot analysis

Genomic DNA $(10 \mu \mathrm{g})$ from PCR positive and wild-type plants was digested with Eco RI and separated on $1 \%$ agarose gel by electrophoresis and then transferred to a nylon membrane. The membrane was hybridized with the Bar probe labeled with digoxingein (DIG) according to the instruction of DIG High Prime DNA Labeling and Detection Starter Kit (Roche, Switzerland). The insertion copy number of the transgene was detected on autoradiography film.

\section{RT-PCR analysis}

The WT and transgenic lines treated with different concentration of $\mathrm{NaCl}(150,250$, and $350 \mathrm{mM})$ for 7 days were harvested. The total RNA extraction was performed in Trizol kit (Invitrogen, USA). First Strand cDNA Synthesis was produced with $2 \mu \mathrm{g}$ total RNA samples using cDNA synthesis supermix (Transgen, China) .The expressions of Bar and SOS1 gene were amplified with reverse transcription PCR (RT-PCR). The primers sequence of Bar and SOS1 were described previously. Amplified fragments were separated on $1 \%$ agarose gel.

Glufosinate resistance

To identify the glufosinate resistance of transgenic plants, $250 \mathrm{mg} / \mathrm{l}$ glufosinate were sprayed on the leaves of the WT and $\mathrm{T}_{1}$ plants of transgenic lines 6-2 and observed the phenotype of plants.

Physiology analysis of transgenic plants

\section{Salt stress treatment}

The WT and $\mathrm{T}_{1}$ generation of transgenic plants were grown in plastic pots filled with a peat moss, vermiculite mixture located in a greenhouse. The plants were treated with nutrient 
solution containing $0,150,250$, and $350 \mathrm{mM} \mathrm{NaCl}$ for 7 days, respectively. The solutions were replaced everyday. The leaves and roots were collected, and the contents and flux of $\mathrm{Na}^{+}$and $\mathrm{K}^{+}$; the activities of superoxide dismutase (SOD), peroxidase (POD), and catalase (CAT); and the contents of malondialdehyde (MDA) and proline (Pro) were measured, respectively, after $350 \mathrm{mM} \mathrm{NaCl}$ treatment.

\section{Determination of $\mathrm{Na}^{+}$and $\mathrm{K}^{+}$contents}

The leaves were collected and dehydrated in an oven at $80{ }^{\circ} \mathrm{C}$ for 2 days. The ash samples were digested with $\mathrm{HNO}_{3}$ overnight, and the contents of $\mathrm{Na}^{+}$and $\mathrm{K}^{+}$were measured by atomic absorption spectrophotometry (Xu et al. 2006).

\section{Ion flux assays}

Net flux of $\mathrm{K}^{+}, \mathrm{Na}^{+}$, and $\mathrm{Ca}^{2+}$ were measured using Noninvasive Micro-test Technique. The scanning ion-selective electrode technique (SIET) using the SIET system (BIO-001B, Younger USA Sci. \&Tech. Corp, Amherst, MA, USA). Microelectrodes were filled with different cocktails by Xuyue Science and Technology Cooperation Limited as described previously (Yue et al. 2012). Net ion flux were measured from the root epidermis in mature (2-3 mm from the root tip) and meristematic (120 $\mu \mathrm{m}$ from the tip) zones. During measurements, the software controlled the PatchMan NP2 to move the electrodes between two positions, 50 and $350 \mu \mathrm{m}$ from the root surface in a 10-s square-wave manner. The software also recorded electric potential differences from the electrodes between the two positions using a DAS08 analogue to digital card (Computer Boards, USA) in the computer.

\section{Enzyme activity measurements of SOD, POD, and CAT and content detection of MDA and Pro}

Pro content was measured according to Bates method (Bates et al. 1973). SOD activity was measured according to Beauchamp and Fridovich method (Beauchamp and Fridovich 1971). CAT activity was determined as described by Beers and Sizers method (Beers and Sizers 1952). Measurements of POD activity were carried out according to Gong (2001). MDA content was determined by thiobarbituric acid (TBA) test (Draper et al. 1993).

\section{Results}

Transformation of tall fescue

After an extensive genotype screening, Arid 3, one of the most tissue culture-responsive commercial varieties, was chosen for all transformation experiments (Electronic supplementary material,
Table 2). The construct was introduced into embryogenic calli via Agrobacterium-mediated transformation (Fig. 2a). The infected calli were co-cultured for 3 days (Fig. 2b). Putative transgenic calli were selected on plants containing $5 \mathrm{mg} / \mathrm{l}$ glufosinate for 4 weeks. Glufosinate-resistant calli were white or light yellow, and grew the buds, whereas non-transgenic calli gradually turned brown (Fig. 2c). Shoots emerged from the explants on media containing $2 \mathrm{mg} / \mathrm{l}$ glufosinate. After 3 weeks, putative transformed plants grew quickly and formed strong root systems (Fig. 2d). Subsequently, the transformed plants were transformed to the greenhouse for acclimatization (Fig. 2e, f).

\section{Molecular identification of transgenic plants}

To validate whether the target genes integrated into the tall fescue genome, PCR reactions were first performed with primers designed to amplify the sequence of Bar, SOS1, SOS2, SOS3, and CBL10 genes individually (Fig. 3a-e). We totally obtained 47 bar-resistant lines and further identified by PCR.

The integration of the Bar gene into the Tall fescue genome was further confirmed by southern blot. The genomic DNA was digested by EcoRI and hybridized with the Bar probe. Among the six tested transgenic lines, four out of six lanes showed one to two hybridization signals, whereas no hybridization signals was detected in wild-type plants(Fig. 3f).

Expressions of the Bar gene and SOS1 gene were confirmed by RT-PCR analysis. A Bar band with the expected size of (463 bp) and an SOS1 band with the expected size of (700 bp) were amplified from transgenic lines having salt stress but nothing from wild-type plants (Fig. 3g).

\section{Identification of glufosinate resistance}

The wild-type plants could not resist the glufosinate, and the leaves became dry yellow and withered after 3 days; however, the leaves of transgenic plants maintained green and grew normal (Fig. 4).

Enhanced salt tolerance in the transgenic plants

Based on the identification of glufosinate resistance, 12 plants of $\mathrm{T}_{1}$ generation line 6-2 and WT were selected, respectively, and treated with different concentrations of $\mathrm{NaCl}(0,150,250$, and $350 \mathrm{mM}$ ) to analyze salt tolerance, and each treatment was triplicates. After 7 days, obvious phenotypic differences were observed between wild type and transgenic line 6-2. Wildtype plants showed growth retardation, whereas the transgenic plants displayed normal growth (Fig. 5).

$\mathrm{Na}^{+}$and $\mathrm{K}^{+}$accumulation in transgenic plants

To test whether overexpression of these genes can reduce $\mathrm{Na}^{+}$ accumulation in plants, we compared the $\mathrm{Na}^{+}$and $\mathrm{K}^{+}$contents 
Fig 2 Arobacterium transformation of tall fescue. a Embryogenic calli, b co-culture, c shoot differentiation of callus, $\mathbf{d}$ shoot differentiation of callus, $\mathbf{e}, \mathbf{f}$ transgenic plants in the greenhouse
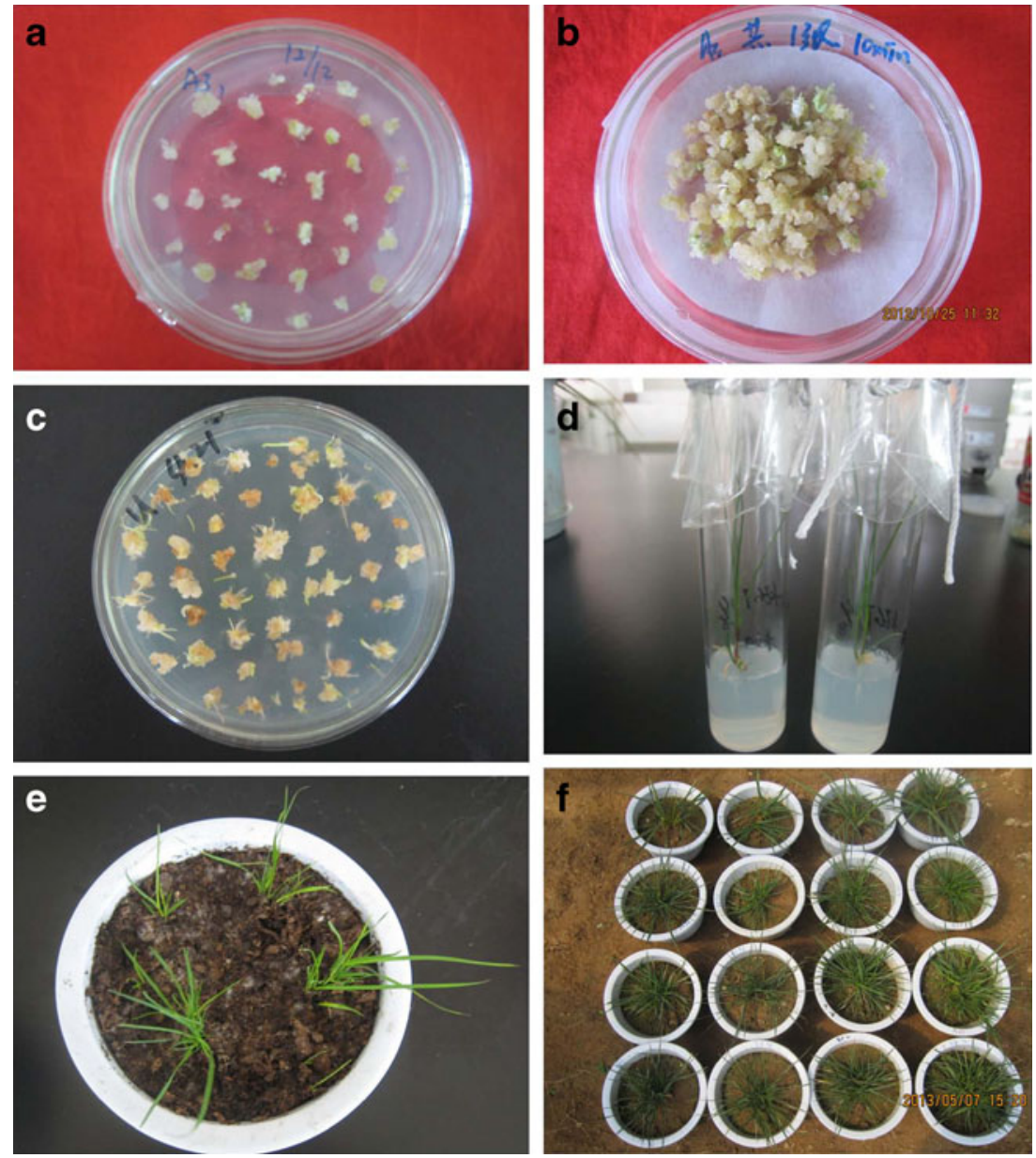

among the transgenic and WT plants. $\mathrm{Na}^{+}$and $\mathrm{K}^{+}$contents in leaves were determined with atomic emission spectrophotometer. $\mathrm{Na}^{+}$and $\mathrm{K}^{+}$contents were similar between transgenic and WT plants without $\mathrm{NaCl}$ treatment. With the $350 \mathrm{mM}$ concentration of salt, the $\mathrm{Na}^{+}$concentration in leaves of transgenic and wildtype plants also increased. However, the wild-type plants accumulated more salt in leaves than transgenic plants (Fig. 6a). At $350 \mathrm{mM}$ of salt stress, the wild-type plants withered after 7 days, whereas transgenic plants showed normal growth and produced new leaves.

The $\mathrm{K}^{+}$contents in the leaves of transgenic and wild-type plants increased as the $\mathrm{NaCl}$ concentration increased, whereas there was significant difference of $\mathrm{K}^{+}$content between leaves of wild-type and transgenic plants, the $\mathrm{K}^{+}$content of transgenic plants in leaves are more than the wild-type plants under salt treatment (Fig. 6b).

Non-invasive ion flux measurements

$\mathrm{K}^{+}$efflux in WT and $\mathrm{K}^{+}$influx in transgenic plants were showed without $\mathrm{NaCl}$ treatment. Salinity stress caused significant changes in net ion flux, and $350 \mathrm{mM} \mathrm{NaCl}$ treatment caused a $\mathrm{K}^{+}$efflux in roots both for WT and transgenic plants (Fig. 7a). Roots of transgenic plants lost less $\mathrm{K}^{+}$instantaneously than did WT plants. $\mathrm{NaCl}$ treatment increased the mean rate of $\mathrm{K}^{+}$flux for both $\mathrm{WT}$ and transgenic plants (Fig. 7b). However, the mean rates of $\mathrm{K}^{+}$flux in transgenic plants were smaller than WT plants without or with $\mathrm{NaCl}$ treatments.

$\mathrm{Na}^{+}$uptake, transport, and compartmentation are crucial for plants to survive saline environments with high $\mathrm{NaCl}$ content. $\mathrm{Na}^{+}$flux are influx in root of transgenic plants, while $\mathrm{Na}^{+}$flux are efflux in roots of WT plants without $\mathrm{NaCl}$ treatment. The transgenic plants and WT plants are treated with $350 \mathrm{mM}$ $\mathrm{NaCl}$ for 7 days, salt induced $\mathrm{Na}^{+}$efflux both in roots of transgenic plants and WT plants (Fig. 8a). The mean rates of $\mathrm{Na}^{+}$flux in transgenic plants were more than WT plants with $\mathrm{NaCl}$ treatments (Fig. 8b).

$\mathrm{Ca}^{2+}$ efflux was significantly higher in the root of WT plants than in transgenic plants in normal condition. Higher $\mathrm{Ca}^{2+}$ influx was observed in roots both for WT and transgenic plants treated with $350 \mathrm{mM} \mathrm{NaCl}$ for 7 days (Fig. 9a). However, the mean rates of $\mathrm{Ca}^{2+}$ influx in transgenic plants increased apparently than WT plants with $\mathrm{NaCl}$ treatment (Fig. 9b). 

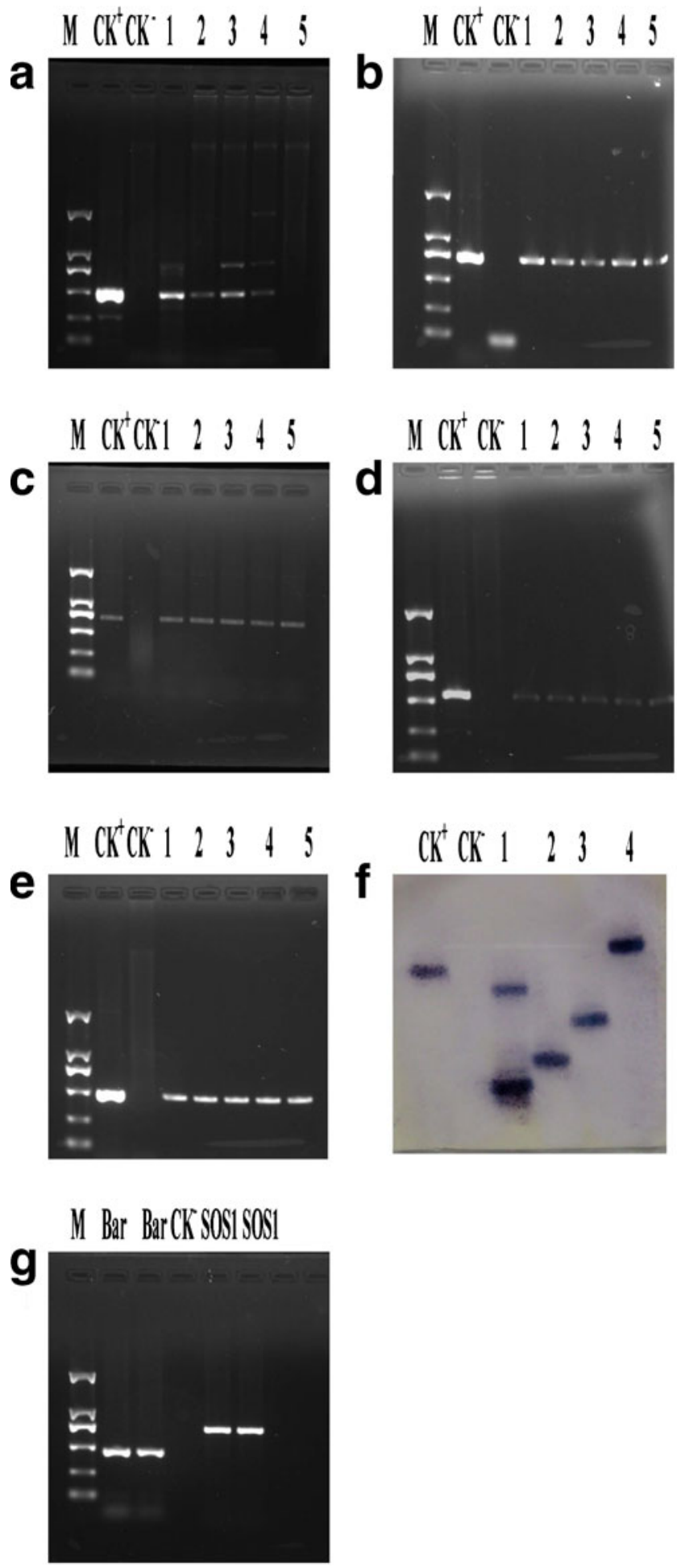

Changes of physiological characteristics

The Pro content of transgenic and wild-type plants was measured before and after salt treatment. Before the salt stress, the Pro content was almost same in both types of plants. However,
Fig. 3 Molecular analysis of wild-type and transgenic lines of tall fescue. a PCR amplification of 463 bp Bar gene. M, DL2000 marker, $\mathrm{CK}^{+}$, plasmid, $\mathrm{CK}^{-}$, wild-type, lanes 1,2,3, and 4 represent PCR amplicon from line 6-2, 6-3, 6-4, 6-5, and 6-6, respectively. b PCR amplification of 700 bp SOS1 gene. c PCR amplification of 550 bp SOS2 gene. d PCR amplification of 683 bp SOS3 gene. e PCR amplification of 460 bp CBL10 gene. f Analysis of transgenic tall fescue plants (lanes 1-6) by southern blot hybridization after digesting genomic. DNA with Eco I and probing with labeled Bar. $M$ molecular marker, $W$ wild-type plant. g RT-PCR analysis of Bar and SOS1 transcripts in transgenic plants. $M$, DL2000 marker, lanes 1 and 2 represent Bar amplicon from lines 6-2 and 6-3. Lane 3 represents Bar amplicon from WT. Lanes 4 and 5 represent SOS1 PCR amplicons from lines 6-2 and 6-3, respectively

an obvious increase was observed in the transgenic and wild plants, which resulted in an about ninefold to fourfold higher Pro content level in the transgenic and wild plants after salt stress, and the Pro content in the leaves of transgenic plants was significantly higher than wild types (Fig. 10a).

The SOD activity change was obviously different between the transgenic and wild-type plants. Under salt stress, the SOD activity in all transgenic plants showed only a slight increase, while SOD activity in the wildtype plants increased significantly (Fig. 10b). The CAT activity was also similarly increased in the transgenic plants after salt stress; however, the CAT activity in wild-type plants reduced slightly compared to what observed before treatment (Fig. 10c). The POD activity increased both in the transgenic and wild-type plants after salt stress, while the increase in the transgenic plants was significantly higher than that of the wild-type plants (Fig. 10d). The MDA content increased in wild-type plants after salt stress; however, the MDA content decreased in transgenic plants (Fig. 10e).

\section{Discussion}

To date, the majority of studies reported are involved in the manipulation of single genes in the improvement of salt tolerance. However, salt tolerance is associated with the interactions of many genes; thus, co-overexpression strategy of multi-genes is a promising way to improve salt tolerance. In this study, $S O S 1+S O S 2+S O S 3$ were in combination in one vector, with each gene being driven by a stress-inducible $r d 29 A$ promoter, respectively. We obtained 47 transgenic lines and one transgenic line 62 was selected to test the salt tolerance. Our results indicated that co-expression of these three SOS pathway genes confers enhanced salt tolerance in transgenic tall fescue. 
Fig. 4 Resistant glufosinate test of $\mathrm{T}_{1}$ transgenic plants. $W T$ wildtype plants, 6-2 $\mathrm{T}_{1}$ transgenic line, 6-2-1 6-2-2 unresistant glufosinate plants of 6-2 $\mathrm{T}_{1}$ transgenic lines, 6-2 -3 6-2-4 resistant glufosinate plants of 6-2 $\mathrm{T}_{1}$ transgenic lines

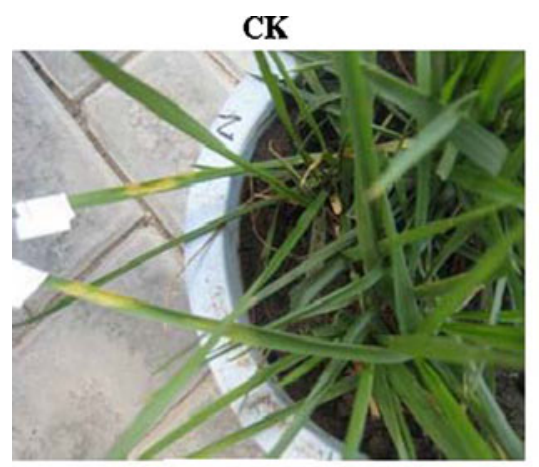

6-2-1

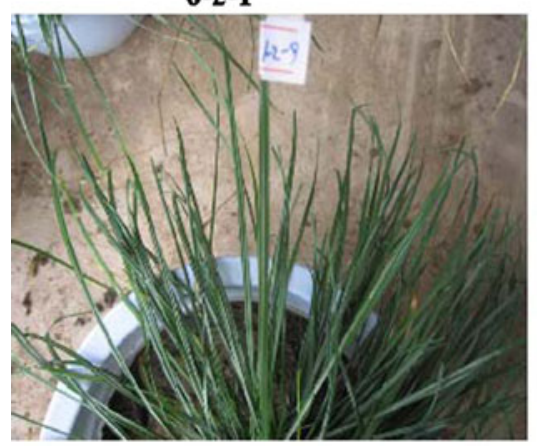

6-2-3

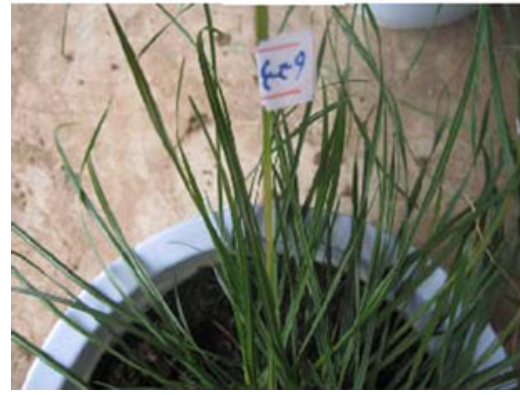

6-2-1 6-2-2 CK 6-2-3 6-2-4

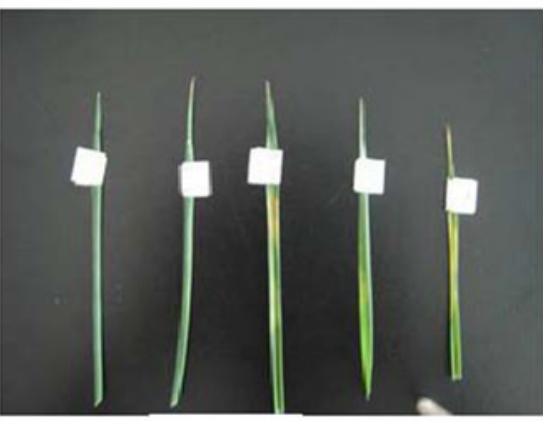

6-2-2

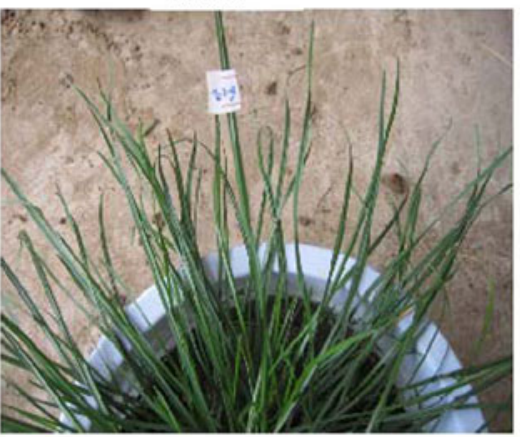

6-2-4

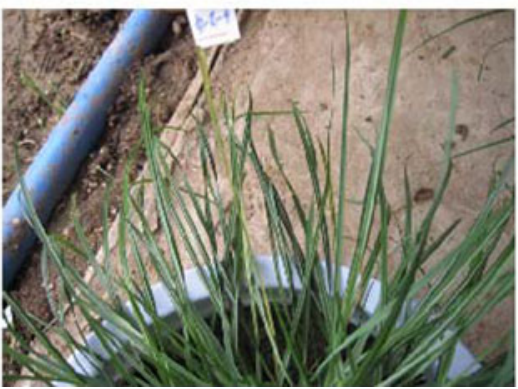

In addition, symptoms of major damage caused by salt stress, such as growth retardation, yellowing of old leaves, and death of older leaves, were moderated in transgenic plants
(Fig. 5) as compared to WT controls. The transgenic lines 6-2 exhibited greatly improved phenotype over WT plants in salt stress, indicating that co-expression of SOS genes confers
Fig. 5 Phenotype of wild-type and transgenic plants under salt stress with different salt concentration for 7 days. $W T$ wild type, $T R$ transgenic plant. 0,150 , 250 , and 350 represent 0,150 , 250 , and $350 \mathrm{mM} \mathrm{NaCl}$ treatment

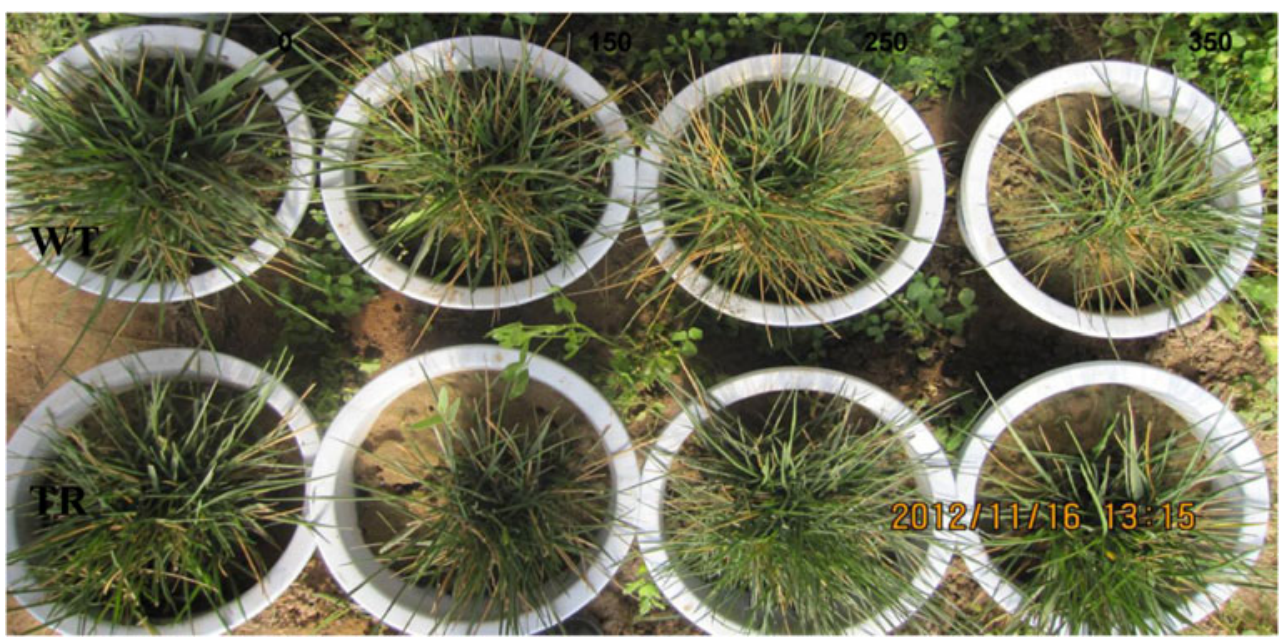


Fig. $6 \mathrm{Na}^{+}$(a) and $\mathrm{K}^{+}$(b) content changes in the transgenic plants and wild-type plants in leaves under salt stress. $C K$ wildtype plant, 6-2 transgenic line

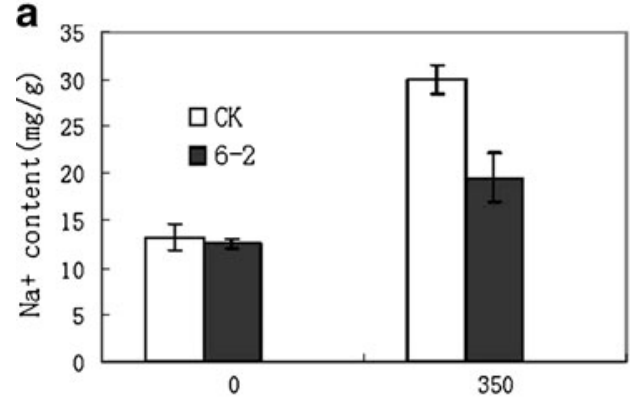

$\mathrm{NaCl}$ concentration $(\mathrm{mM})$

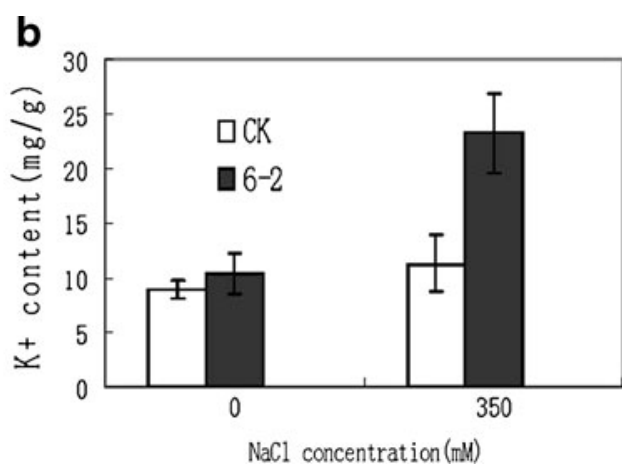

enhanced salt tolerance in tall fescue. This performance was consistent with tall fescue overexpression of $O s N H X 1$, a vacuolar $\mathrm{Na}^{+} / \mathrm{H}^{+}$antiporter (Chen et al. 2007). These results further suggest the potential use of transgenic tall fescue in the co-expression of SOS genes in saline soil. Therefore, the analysis of salt tolerance in transgenic plants showed coexpression of SOS pathway genes and CBL10 gene could improve the salt tolerance of transgenic plants, which were consistent with glufosinate resistance test (Fig. 4).
The salt tolerance of plants is associated with the ability to extrude $\mathrm{Na}^{+}$from the root and maintain a low $\mathrm{Na}^{+} / \mathrm{K}^{+}$ratio in the cell. Transgenic plants overexpression SOS1 (driven by the $35 \mathrm{~S}$ promoter) apparently reduced $\mathrm{Na}^{+}$accumulation (Shi et al. 2003). The $\mathrm{Na}^{+}$accumulation in transgenic plants with overexpression of $S O S 3, A t N H X 1+S O S 3, S O S 2+S O S 3$, or $\mathrm{SOS} 1+\mathrm{SOS} 2+\mathrm{SOS} 3$, respectively, was reduced as compared to that in wild-type plants under salt treatment (Yang et al. 2009). SOS $2 / S O S 3$ complex regulates the expression level of
Fig. 7 Effect of salinity $(350 \mathrm{mM}$ $\mathrm{NaCl}$ ) on net $\mathrm{K}^{+}$flux (influx negative) measured in roots of transgenic lines (6-2) and wildtype (WT) plants. $C K-0$ wild-type plant without treatment, $C K-350$ wild-type plants with $350 \mathrm{mmol}$ $\mathrm{NaCl}$ treatment, 6-2-0 transgenic lines 6-2 without treatment, 6-2350 transgenic lines 6-2 with $350 \mathrm{mM} \mathrm{NaCl}$ treatment. a $\mathrm{K}^{+}$ flux for WT and transgenic plants roots. $\mathbf{b}$ The mean rate of $\mathrm{K}^{+}$flux during the period of salt-stress treatment

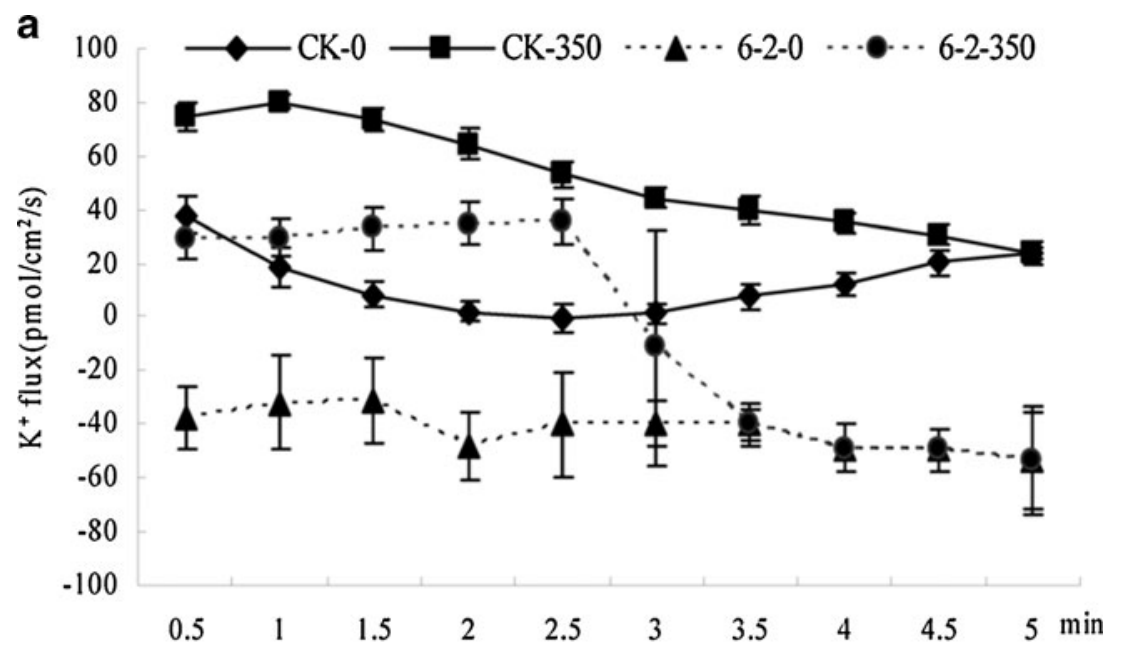

b

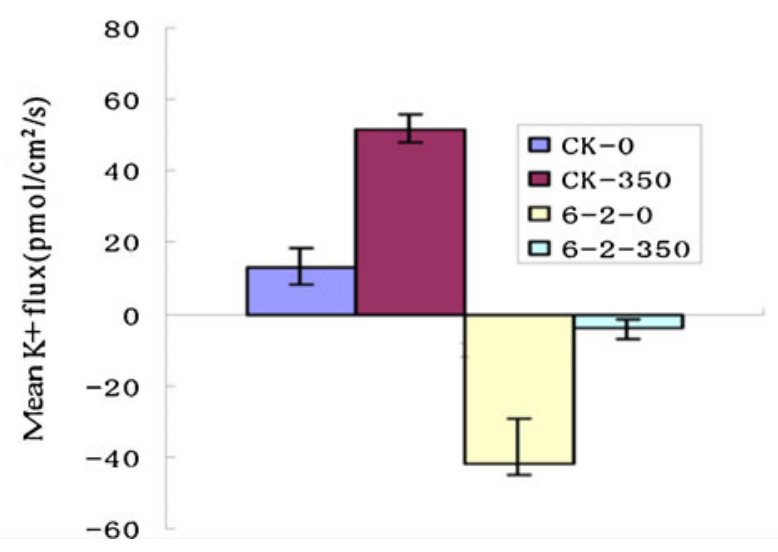


Fig. 8 Effect of salinity $(350 \mathrm{mM}$ $\mathrm{NaCl}$ ) on net $\mathrm{Na}^{+}$flux (influx negative) measured in roots of transgenic lines (6-2) and wildtype (WT) plants. $C K-0 \mathrm{WT}$ plants without treatment, $C K-350$ WT plants with $350 \mathrm{mmol} \mathrm{NaCl}$ treatment, 6-2-0 transgenic lines 6-2 without treatment, 6-2-350 transgenic plants with $350 \mathrm{mmol}$ $\mathrm{NaCl}$ treatment. a $\mathrm{Na}^{+}$flux for WT and transgenic plants roots. b The mean rate of $\mathrm{Na}^{+}$flux during the period of salt-stress treatment

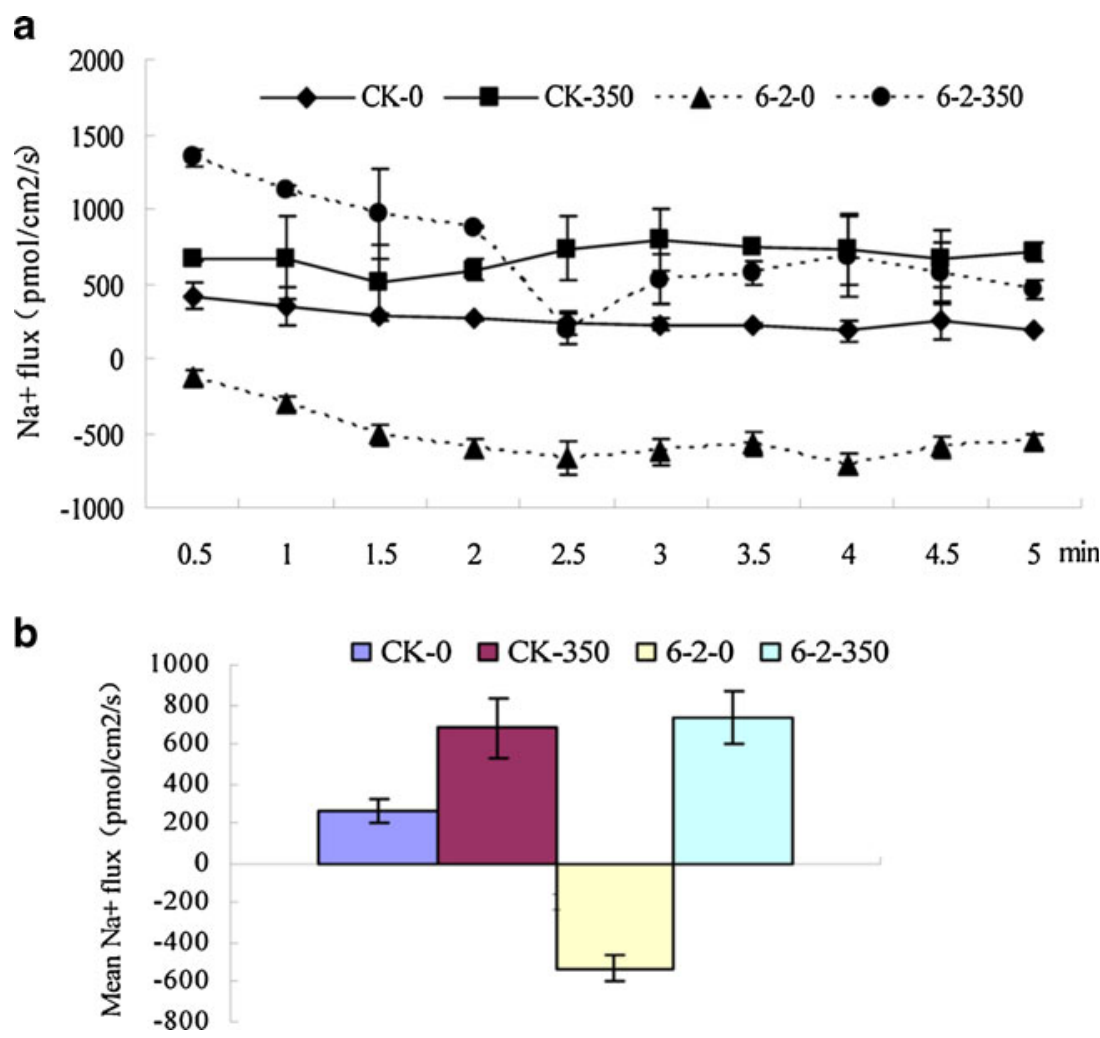

a salt tolerance effector gene encoding $S O S 1$, a plasma membrane $\mathrm{Na}^{+} / \mathrm{H}^{+}$antiporter, which extrudes excess $\mathrm{Na}^{+}$from the cytosol (Shi et al. 2000). The SOS signal transduction pathway has also been shown to be involved in $\mathrm{K}^{+}$acquisition by roots (Wu et al. 1996; Zhu et al. 1998). SOS1-overexpressing seedlings with $150 \mathrm{mM} \mathrm{NaCl}$ stress accumulated less $\mathrm{Na}^{+}$and more $\mathrm{K}^{+}$(Yue et al. 2012). Similar to those with the previous results, we found that $S O S 1+S O S 2+S O S 3$ - and CBL10overexpressing transgenic plants accumulated less $\mathrm{Na}^{+}$than WT plants under salt stress $(350 \mathrm{mM} \mathrm{NaCl})$ (Figs. 6a and 8a, b). Therefore, co-expression of the Arabidopsis SOS genes (SOS1/SOS2/SOS3) and CBL10 can extrude $\mathrm{Na}^{+}$from the cytoplasm in tall fescue roots and leaves, mitigate the toxic effects of $\mathrm{Na}^{+}$, and improve salt tolerance under $\mathrm{NaCl}$ stress, and this may be due to the SOS pathway and CBL10 which are responsible for $\mathrm{Na}^{+}$homeostasis in plants. $C B L 10$ and $S O S 3$ must fulfill distinct regulatory functions in the salt stress response, as they could not replace each other in genetic complementation. Salt stress can induce SOS2 phosphorylates $C B L 10$ at the plasma membrane, stabilizes the CBL10-SOS2 interaction, and enhances plasma membrane $\mathrm{Na}^{+} / \mathrm{H}^{+}$exchange activity (Lin et al., 2009). SOS3 and SOS2 are involved in sensing and responding to the influx of sodium ions. This complex activates $S O S 1$, a plasma membrane-located sodium/proton antiporter. Activation of SOS1 mediates the export of the $\mathrm{Na}^{+}$ions (Lin et al. 2009). Therefore, co-expression SOS pathway genes and CBL10 gene could make the transgenic plants decrease accumulation of $\mathrm{Na}^{+}$and mitigate the toxic effects of $\mathrm{Na}^{+}$.

Adaptation of plants to saline environments not only depends on their ability to avert the toxic effects of $\mathrm{Na}^{+}$but also on their ability to overcome salt-induced injury, and it was closely related with $\mathrm{K}^{+}$uptake and $\mathrm{K}^{+}$homeostasis. Salinity may reduce $\mathrm{K}^{+}$uptake as a result of competition between $\mathrm{Na}^{+}$ and $\mathrm{K}^{+}$for plasma membrane uptake sites (Tyerman and Skerrett 1999; Maathuis and Amtmann 1999; Tester and Davenport 2003). SOS1 protected the AKT1 of $\mathrm{K}^{+}$channel, which mediated $\mathrm{K}^{+}$influx in the presence of increased $\mathrm{Na}^{+}(\mathrm{Q} i$ and Spalding 2004; Shabala et al. 2005). Consistent with those reports, our results showed that $\mathrm{K}^{+}$efflux from the elongation region of roots of transgenic plants overexpressing $\mathrm{SOS} 1+$ $S O S 2+S O S 3$ was smaller than that from WT plants (Figs. $6 \mathrm{~b}$ and $7 \mathrm{a}, \mathrm{b}$ ). These may be due to the SOS signal transduction pathway which is also involved in $\mathrm{K}^{+}$acquisition in roots. We assumed that the transgenic tall fescue having lower $\mathrm{Na}^{+}$levels and higher $\mathrm{K}^{+}$levels in the leaves and roots, respectively, in salt stress, is likely because the co-expression of the $S O S$ genes could affect $\mathrm{K}^{+}$transported by $\mathrm{Na}^{+}$levels and promote $\mathrm{K}^{+}$uptake to maintain $\mathrm{K}^{+}$homeostasis.

$\mathrm{Ca}^{2+}$ has been widely implicated as an intracellular messenger of physiologically and environmentally induced signaling pathways in plants (Trewavas and Malho 1998). Because cellular $\mathrm{Ca}^{2+}$ levels are tightly 
regulated, small changes in intracellular $\mathrm{Ca}^{2+}$ can provide information for the modification of enzyme activity and gene expression needed for subsequent responses (Guo et al. 2004). Salt stress elicits a transient increase of $\mathrm{Ca}^{2+}$ that is sensed by $\mathrm{SOS} 3$, a myristoylated calcium-binding protein, which interacts with and activates $S O S 2$, a serine/threonine protein kinase. The SOS2/SOS3 kinase complex phosphorylates and activates the SOS1 protein (Qiu et al. 2002; Zhu 2003). Kun-Mei Guo found that the SOS mutations alter the activity of $\mathrm{Ca}^{2+}$ transport systems in normal and $\mathrm{NaCl}$ affected conditions, and all SOS mutations led to increased $\mathrm{Ca}^{2+}$ influx into the meristem cells in comparison with WT in the absence of salt stress because SOS mutants are needed to increase $\mathrm{Ca}^{2+}$ sequestration into internal cell compartments to maintain $\left[\mathrm{Ca}^{2+}\right]_{c y t}$ at the WT level (Guo et al. 2009). An increase in $\left[\mathrm{Ca}^{2+}\right]_{\mathrm{cyt}}$ during $\mathrm{NaCl}$ stress has been reported by Kiegle et al. (2000). $\mathrm{Ca}^{2+}$ regulation of SOS3 has been observed previously (Gong et al. 2004). Based on the combination of previous studies and data presented here (Fig. 9a, b), the mean rates of $\mathrm{Ca}^{2+}$ influx in transgenic plants increased apparently than in WT plants with $350 \mathrm{mM} \mathrm{NaCl}$ treatment. We suggested that there were links between $\mathrm{Ca}^{2+}$ transport and $\mathrm{SOS}$ pathway ( $\mathrm{SOS1-}$
SOS2-SOS3) and the regulation of $\mathrm{Na}^{+}$and $\mathrm{Ca}^{2+}$ homeostasis in tall fescue. Earlier report demonstrated that SOS1 was apparently involved in enhancing $\mathrm{Ca}^{2+}$ transport in NaCl-affected conditions (Guo et al. 2009). The $C B L 10$ gene was shown to bind calcium, interact with SOS2 both in vitro and in vivo, recruit SOS2 to the plasma membrane, enhance SOS2 activity in a calciumdependent manner, and activate SOS1 in yeast (Quan et al. 2007). The CBL10 gene is associated with membrane fractions. This membrane localization is consistent with the idea that many $\mathrm{Ca}^{2+}$-signaling events are initiated by $\mathrm{Ca}^{2+}$ fluxes across membranes (Rudd and Franklin-Tong 1999). Moreover, calcium is widely recognized to play an important part in regulating the passive entry of $\mathrm{Na}^{+}$and in $\mathrm{K}^{+} / \mathrm{Na}^{+}$selectivity. Thus, it is probable that the enhanced root levels of $\mathrm{Ca}^{2+}$ in transgenic plants could guarantee the integrity of its membranes, allowing the change in $\mathrm{K}^{+} / \mathrm{Na}^{+}$and the selective absorption of $\mathrm{K}^{+}$. However, there was a significant difference in $\mathrm{K}^{+}, \mathrm{Na}^{+}$, and $\mathrm{Ca}^{2+}$ flux between the WT and transgenic plants under non-salt treatment. This would be the reason of difference in root zone at the same distance $(500 \mu \mathrm{m})$ between them.

Salinity could generate ion toxicity to cell, which caused reactive oxygen species (ROS) and proline accumulation
Fig. 9 Effect of salinity $(350 \mathrm{mM}$ $\mathrm{NaCl}$ ) on net $\mathrm{Ca}^{+}$flux (influx negative) measured in roots of transgenic lines (6-2) and wildtype $(W T)$ plants. $C K-0$ WT plants without treatment, $C K-350$ WT plants with $350 \mathrm{mmol} \mathrm{NaCl}$ treatment, 6-2-0 transgenic lines 6-2 without treatment, 6-2-350 transgenic lines 6-2 with $350 \mathrm{mmol} \mathrm{NaCl}$ treatment. a $\mathrm{Ca}^{2+}$ flux for WT and transgenic plants in roots. $\mathbf{b}$ The mean rate of $\mathrm{Ca}^{+}$ flux during the period of saltstress treatment

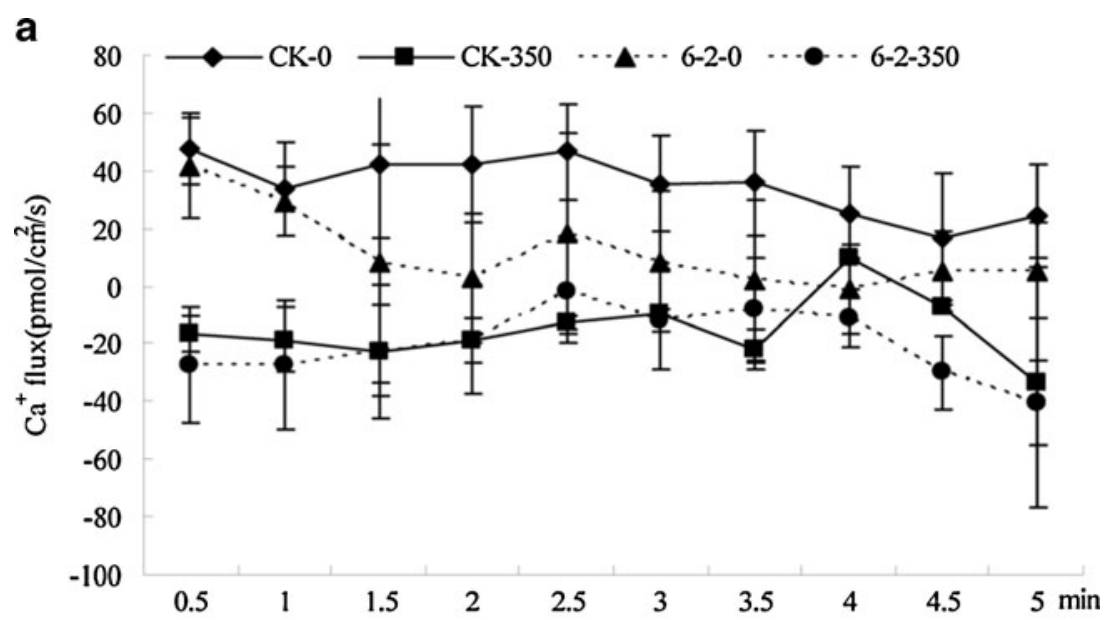

b

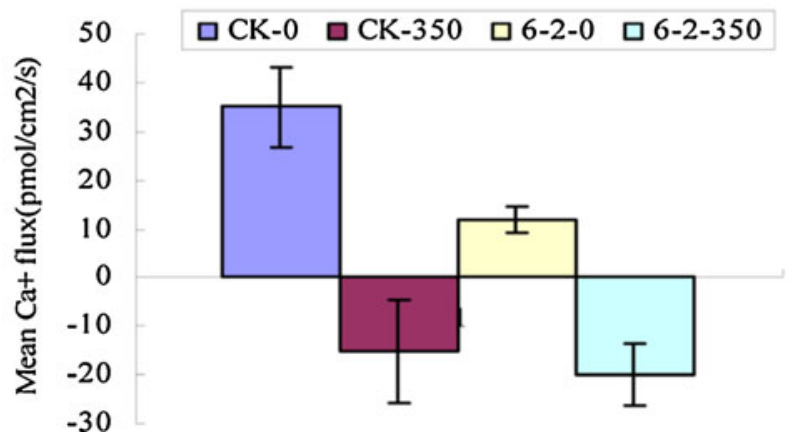




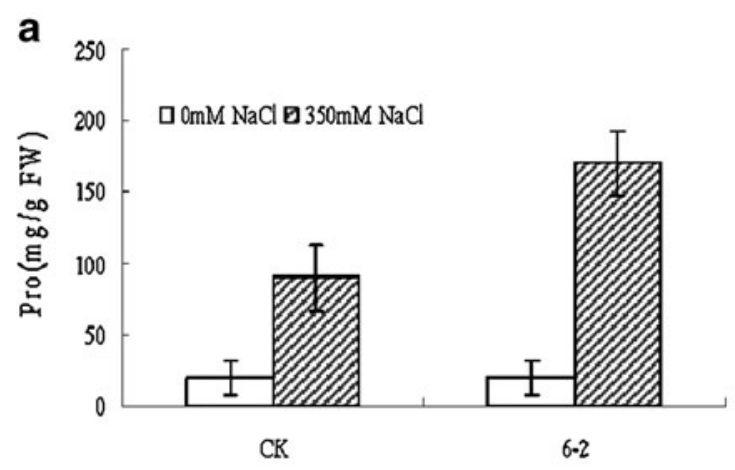

b

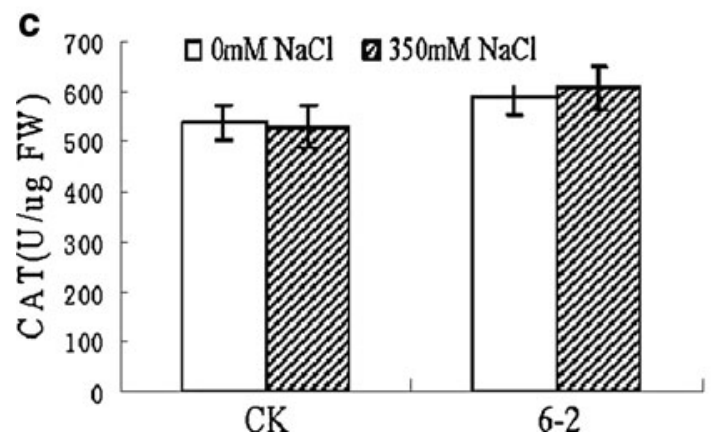

Fig. 10 Changes of physiological characteristics in the leaves of transgenic and wild-type plants with or without salt stress. $C K$ wild-type plant, 6-2 transgenic line. a The proline (Pro) content, $\mathbf{b}$ the enzyme superoxide
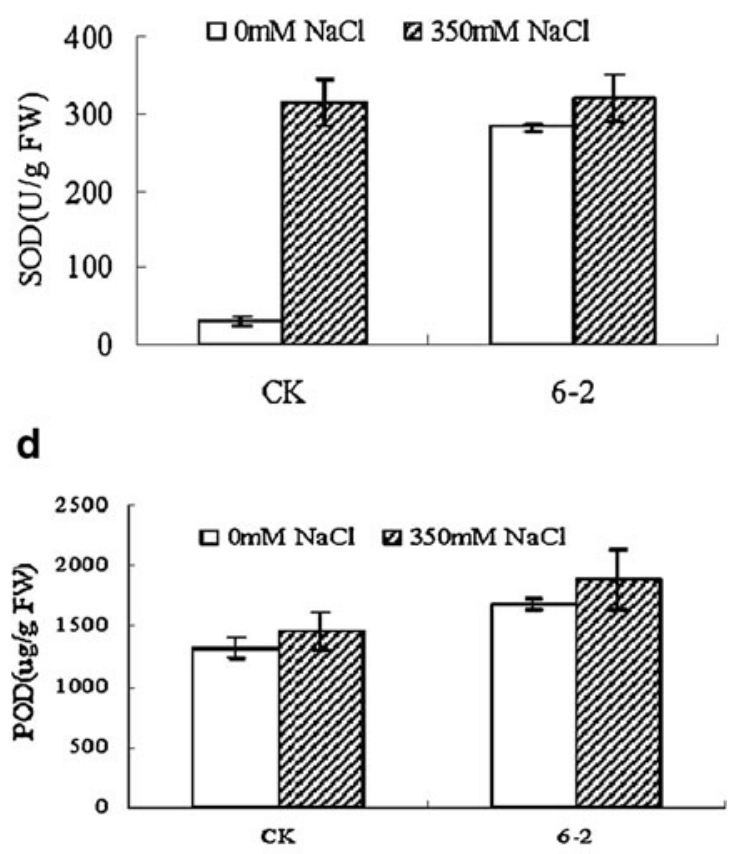

dismutase $(S O D)$ activity, $\mathbf{c}$ the enzyme catalase (CAT) activity, $\mathbf{d}$ the enzyme peroxidase $(P O D)$ activity, e the malondialdehyde $(M D A)$ content

in plants (Greenway and Munns 1980; Xiong et al. 2002). The ROS accumulation leads to the instability of the cell membrane system and inhibits plant growth and development (Li et al. 2011). The SOD, POD, and CAT are the important antioxidation enzymes for decreasing ROS harm and maintaining the integrity of the cellular membrane construction (Li et al. 2011). In this report, we assayed the changes of physiological characteristics including SOD, POD, and CAT activity and content of MDA and Pro. In transgenic tall fescue, the $\mathrm{Na}^{+}$could not generate serious ion toxicity to cell and the excessive $\mathrm{Na}^{+}$induced SOD, POD, and CAT activity to decrease ROS accumulation (Figs. 6a and 10b-d). However, ROS might not be scavenged by SOD, POD, and CAT instantly and effectively, which caused the significant rise of the Pro content. This might have been more severe with higher $\mathrm{Na}^{+}$contents of the cell with $350 \mathrm{mM} \mathrm{NaCl}$ treatments. For WT, without SOS pathway genes and $C B L$ gene, the absorbed $\mathrm{Na}^{+}$could not be efficiently mediated by $\mathrm{Na}^{+}$ efflux to maintain a sufficiently low $\mathrm{Na}^{+}$concentration in cytoplasm; therefore, the higher $\mathrm{Na}^{+}$contents induced SOD, POD, and CAT activity and Pro content were inferior to transgenic tall fescue. These results implied that the $\mathrm{Na}^{+}$content of cytoplasm in transgenic tall fescue could be kept at a low level and the SOS pathway genes and CBL10 gene accelerated a large

amount of $\mathrm{Na}^{+}$efflux. Consequently, the co-expression of SOS pathway genes and CBL10 gene could efficiently maintain $\mathrm{Na}^{+}$homeostasis of cytoplasm and improve salt tolerance of transgenic plants.

The MDA content of WT showed a significant increase in comparison to transgenic plants with $350 \mathrm{mM} \mathrm{NaCl}$ treatment (Fig. 10e). The increased MDA content might be due to the membrane destruction in WT resulting from ROSinduced oxidative damage (Zhang et al. 2007). The salt treatment may be involved in scavenging ROS more efficiently in the transgenic plants. Proline accumulation may be the symptom of injury caused or the adaptive response in salt stress (Fig. 10a) (Riazi et al. 1985; Aspinall and Paleg 1981). Osmoregulation has been attributed to Pro accumulation in tissues of the plants in response to salt stress (De and Maiti 1995). Moreover, Pro would stabilize enzymes as RUBISCO, allowing its efficient functioning even in the presence of $\mathrm{NaCl}$ (Solomon et al. 1994).

In summary, we obtained 47 transgenic tall fescue lines via Agrobacterium-mediated transformation. Moreover, a typical line 6-2 was further used to investigate its salt tolerance. Results from the contents and flux of $\mathrm{Na}^{+}, \mathrm{K}^{+}$, and $\mathrm{Ca}^{2+}$ and the physiological traits illustrated that the $S O S 1+S O S 2+$ SOS3-overexpressing transgenic tall fescue had enhanced tolerance to salt stress. Our result may provide a new insight in molecular breeding of turfgrass and be helpful in exploiting and utilizing saline soil. 
Acknowledgments We would like to thank Professors Xuechen Wang and Qijun Chen from the College of Biological Sciences in China Agricultural University for providing the vector. This work was supported by a grant from the Key Project of Chinese National Programs for Fundamental Research and Development (973 program, 2012CB114204) and grants from Chinese National Key Technology R\&D Program (2011BAC07B03).

Conflict of interest The authors declare that they have no conflict of interest.

Open Access This article is distributed under the terms of the Creative Commons Attribution License which permits any use, distribution, and reproduction in any medium, provided the original author(s) and the source are credited.

\section{References}

Allen GC, Spiker S, Thompson WF (2000) Use of matrix attachment regions (MARs) to minimize transgene silencing. Plant Mol Biol 43: 361-376

Aspinall D, Paleg LG (1981) Proline Accumulation: Physiological Aspects. In The Physiology and Biochemistry of Drought Resistance in Plants. Academic Press, Australia, pp 205-241

Bates LS, Waldren RP, Teare ID (1973) Rapid determination of free proline for water-stress studies. Plant Soil 39:205-207

Beauchamp C, Fridovich I (1971) Superoxide dismutase: improved assays and an assay applicable to acrylamide gels. Anal Biochem 44:276-287

Beers R, Sizer T (1952) Spectrophotometric method for measuring the breakdown of hydrogen peroxide by catalase. J Biol Chem 195: $133-138$

Berres R, Otten L, Tinland B, Malgarini-Clog E, Walter B (1992) Transformation of vitis tissue by different strains of Agrobacterium tumefaciens containing the T-6b gene. Plant Cell Rep 11:192-195

Cao YJ, Wei Q, Liao Y, Song HL, Li X, Xiang CB, Kuai BK (2009) Ectopic overexpression of AtHDG11 in tall fescue resulted in enhanced tolerance to drought and salt stress. Plant Cell Rep 28:579-588

Chen H, An R, Tang JH, Cui XH, Hao FH, Chen J, Wang XC (2007) Over-expression of a vacuolar $\mathrm{Na}^{+} / \mathrm{H}^{+}$antiporter gene improves salt tolerance in an upland rice. Mol Breeding 19:215-225

Chen QJ, Xie M, Ma XX, Dong L, Chen J, Wang XC (2010) MISSA is a highly efficient in vivo DNA assembly method for plant multiplegene transformation. Plant Physiol 153:41-51

Chen L, Ren F, Zhou L, Wang QQ, Zhong H, Li BX (2012) The Brassica napus calcineurin B-Like 1/CBL-interacting protein kinase 6 (CBL1/CIPK6) component is involved in the plant response to abiotic stress and ABA signaling. J Exp Bot 63:6211-6222

De LR, Maiti RK (1995) Biochemical mechanism in glossy sorghum lines for resistance to salinity stress. J Plant Physiol 146:515-519

Draper HH, Squires EJ, Mahmoodi H, Wu J, Agarwal S, Hadley M (1993) A comparative evaluation of thiobarbituric acid methods for the determination of malondialdehyde in biological materials. Free Radic Biol Med 15(4):353-363

Du WM, Lin HX, Chen S, Wu YS, Zhang J, Fuglsang AT, Palmgren MG, Wu WH, Guo Y (2011) Phosphorylation of SOS3-like calcium-binding proteins by their interacting sos2-like protein kinases is a common regulatory mechanism in Arabidopsis. Plant Physiol 156:2235-2243

Ge Y, Wang ZY (2006) Tall fescue (Festuca arundinacea Schreb). Methods Mol Biol (Clifton, NJ) 344:75-81

Gong PB (2001) In: Principles and techniques of plant physiological biochemical experiment. Higher Education Press, Beijing, pp 121-158

Gong DM, Guo Y, Schumaker KS, Zhu JK (2004) The SOS3 family of calcium sensors and SOS2 family of protein kinases in Arabidopsis. Plant Physiol 134:919-926
Greenway H, Munns R (1980) Mechanisms of salt tolerance in non halophytes. Ann Rev Plant Physiol 31:149-190

Guo Y, Qiu QS, Quintero FJ, Pardo JM, Ohta M, Zhang C, Schumaker KS, Zhu JK (2004) Transgenic evaluation of activated mutant alleles of SOS2 reveals a critical requirement for its kinase activity and Cterminal regulatory domain for salt tolerance in Arabidopsis thaliana. Plant Cell 16:435-449

Guo KM, Babourinaa O, Rengela Z (2009) $\mathrm{Na}^{+} / \mathrm{H}^{+}$antiporter activity of the SOS1 gene: lifetime imaging analysis and electrophysiological studies on Arabidopsis seedlings. Physiol Plant 137:155-165

Halfter U, Ishitani M, Zhu JK (2000) The Arabidopsis SOS2 protein kinase physically interacts with and is activated by the calcium-binding protein SOS3. Proc Natl Acad Sci U S A $97: 3735-3740$

Huai JL, Zheng J, Wang GY (2009) Overexpression of a new Cys (2)/His (2) zinc finger protein ZmZF1 from maize confers salt and drought tolerance in transgenic Arabidopsis. Plant Cell Tissue 99:117-124

Jin TC, Chang Q, Li WF, Yin DX, Li ZJ, Wang DL, Liu B, Liu LX (2010) Stress-inducible expression of GmDREBI conferred salt tolerance in transgenic alfalfa. Plant Cell Tissue Org 100:219-227

Kiegle E, Moore CA, Haseloff J, Tester MA, Knight MR (2000) Celltype-specific calcium responses to drought, salt and cold in the Arabidopsis root. J Plant 23:267-278

Lee DG, Kwakc SS, Kwonc SY, Kimd TH, Lee BH (2007) Simultaneous overexpression of both $\mathrm{CuZn}$ superoxide dismutase and ascorbate peroxidase in transgenic tall fescue plants confers increased tolerance to a wide range of abiotic stresses. Acad J Plant Physiol 164: $1626-1638$

Li WF, Wang DL, Jin TC, Chang Q, Yin DX, Xu SM, Liu B, Liu LX (2011) The vacuolar $\mathrm{Na}^{+} / \mathrm{H}^{+}$antiporter gene $S s N H X I$ from the Halophyte Salsola soda confers salt tolerance in transgenic Alfalfa (Medicago sativa L.). Plant Mol Biol Rep 29:278-290

Lin H, Yang Y, Quan R, Mendoza I, Wu Y, Du W, Zhao S, Schumaker K, Pardo JM, Guo Y (2009) Phosphorylation of SOS3-LIKE CALCIUM BINDING PROTEIN8 by SOS2 protein kinase stabilizes their protein complex and regulates salt tolerance in Arabidopsis. Plant Cell 21:1607-1619

Liu JP, Zhu JK (1998) A calcium sensor homolog required for plant salt tolerance. Science 280:1943-1945

Liu J, Ishitani M, Halfter U, Kim CS, Zhu JK (2000) The Arabidopsis thaliana SOS2 gene encodes a protein kinase that is required for salt tolerance. Proc Natl Acad Sci 97:3730-3734

Maathuis FJM, Amtmann A (1999) $\mathrm{K}^{+}$nutrition and $\mathrm{Na}^{+}$toxicity: the basis of cellular $\mathrm{K}^{+} / \mathrm{Na}^{+}$ratios. Ann Bot 84:123-133

Munns R (2002) Comparative physiology of salt and water stress. Plant Cell Environ 25:239-250

Murashige T, Skoog F (1962) A revised medium for rapid growth and bio assays with tobacco tissue cultures. Physiol Plant 15: 473-497

Murray MG, Thompson WF (1980) Rapid isolation of high molecular weight plant DNA. Nucleic Acids Res 8:4321-4325

Qi Z, Spalding EP (2004) Protection of plasma membrane $\mathrm{K}^{+}$transport by the salt overly sensitive $\mathrm{Na}^{+} / \mathrm{H}^{+}$antiporter during salinity stress. Plant Physiol 136:2548-2555

Qiu QS, Guo Y, Dietrich MA, Schumaker KS, Zhu JK (2002) Regulation of SOS1, a plasma membrane $\mathrm{Na}^{+} / \mathrm{H}^{+}$exchanger in Arabidopsis thaliana by SOS2 and SOS3. Proc. Natl Acad Sci 99:8436-8441

Quan RD, Lin H, Mendoza L, Zhang Y, Cao W, Yang Y, Shang M, Chen S, Guo Y (2007) SCABP8/CBL10, a putative calcium sensor, interacts with the protein kinase SOS2 to protect Arabidopsis shoots from salt stress. Plant Cell 19:1415-1431

Quintero FJ, Ohta M, Shi H, Zhu JK, Pardo JM (2002) Reconstitution in yeast of the Arabidopsis SOS signaling pathway for $\mathrm{Na}^{+}$homeostasis. Proc Natl Acad Sci 99:9061-9066 
Riazi A, Matsuda K, Arslan A (1985) Water stress-induced changes in concentrations of proline and other solutes in growing regions of young barley leaves. J Exp Bot 36:1716-1725

Rudd JJ, Franklin-Tong VE (1999) Calcium signaling in plants. Cell Mol Life Sci 55:214-232

Shabala L, Cuin TA, Newman IA, Shabala S (2005) Salinity-induced ion flux patterns from the excised roots of Arabidopsis SOS mutants. Planta 222:1041-1050

Shi H, Ishitani M, Kim C, Zhu JK (2000) The Arabidopsis thaliana salt tolerance gene SOS1 encodes a putative $\mathrm{Na}^{+} / \mathrm{H}^{+}$antiporter. Proc Natl Acad Sci 97:6896-6901

Shi H, Lee BH, Wu SJ, Zhu JK (2003) Overexpression of a plasma membrane $\mathrm{Na}^{+} / \mathrm{H}^{+}$antiporter gene improves salt tolerance in Arabidopsis thaliana. Nat Biotechnol 21:81-85

Sleper DA, West CP (1996) Tall fescue. In: Moser LE, Buxton DR, Casler MD (eds) Cool-season forage grasses. American Society of Agronomy, Crop Science Society of America, Soil Science Society of America, Madison, pp 471-502

Solomon A, Beer S, Waisel Y, Paleg LG (1994) Effects of NaCl on the carboxylating activity of Rubisco from Tamarix jordanis in the presence of proline-related compatible solutes. Physiol Plant 90:198-204

Tester M, Davenport R (2003) $\mathrm{Na}^{+}$tolerance and $\mathrm{Na}^{+}$transport in higher plants. Ann Bot 91:503-527

Tian LM, Huang CL, Yu R, Liang RF, Li ZL, Zhang LS, Wang YQ, Zhang XH, Wu ZY (2006) Overexpression AtNHXI confers salttolerance of transgenic tall fescue. Afr J Biotechnol 5:1041-1044

Trewavas AJ, Malho R (1998) $\mathrm{Ca}^{2+}$ signaling in plant cells: the big network. Curr Opin Plant Biol 1:428-433

Tyerman SD, Skerrett IM (1999) Root ion channels and salinity. Sci Hortic 78:175-235

Wu SJ, Ding L, Zhu JK (1996) SOS1, a genetic locus essential for salt tolerance and potassium acquisition. Plant Cell 8:617-627

Xiong LM, Schumaker KS, Zhu JK (2002) Cell signaling during cold, drought, and salt stress. Plant Cell 14:165-183

Xu J, Li HD, Chen LQ, Wang Y, Liu LL, He L (2006) A protein kinase, interacting with two calcineurin B-like proteins, regulates $\mathrm{K}^{+}$transporter AKT1 in Arabidopsis. Cell 125:1347-1360
Xue H, Yang YT, Wu CA, Yang GD, Zhang MM, Zheng CC (2005) $T M 2$, a novel strong matrix attachment region isolated from tobacco, increases transgene expression in transgenic rice calli and plants. Theor Appl Genet 110:620-627

Yamaguchi-Shinozaki K, Kasuga M, Liu Q, Nakashima K, Sakuma Y, Abe H, Shinwari ZK, Seki M, Shinozaki K (2002) Biological mechanisms of drought stress response. JIRCAS Working, Report: $1-8$

Yang Q, Chen ZZ, Zhou XF, Yin HB, Li X, Xin XF, Hong XH, Zhu JK, Gong ZZ (2009) Overexpression of SOS (Salt Overly Sensitive) genes increases salt tolerance in transgenic Arabidopsis. Mol Plant 2:22-31

Yue YS, Zhang MC, Zhang JC, Duan LS, Li ZH (2012) SOS1 gene overexpression increased salt tolerance in transgenic tobacco by maintaining a higher $\mathrm{K}^{+} / \mathrm{Na}^{+}$ratio. J Plant Physiol 169:255-261

Zhang CF, Hu J, Lou J, Zhang Y, Hu WM (2007) Sand priming in relation to physiological changes in seed germination and seedling growth of waxy maize under high salt stress. Seed Sci Technol 35(3):733-738

Zhao JS, Zhi DY, Xue ZY, Liu H, Xia GM (2005) Research on Festuca arundinacea transformation mediated by Agrobacterium tumefaciens (in Chinese). Acta Genet Sin 32:579-585

Zhao JS, Zhi DY, Xue ZY, Liu H, Xia GM (2007) Enhanced salt tolerance of transgenic progeny of tall fescue (Festuca arundinacea) expressing a vacuolar $\mathrm{Na}^{+} / \mathrm{H}^{+}$antiporter gene from Arabidopsis. J Plant Physiol 164:1377-1383

Zhu JK (2000) Genetic analysis of plant salt tolerance using Arabidopsis. Plant Physiol 124:941-948

Zhu JK (2001) Plant salt tolerance. Trends Plant Sci 6:66-71

Zhu JK (2002) Salt and drought stress signal transduction in plants. Annu Rev Plant Biol 53:247-273

Zhu JK (2003) Regulation of ion homeostasis under salt stress. Curr Opin Plant Biol 6:441-445

Zhu JK, Liu J, Xiong L (1998) Genetic analysis of salt tolerance in Arabidopsis thaliana: evidence of a critical role for potassium nutrition. Plant Cell 10:1181-1192 